\title{
Konrad Wallenrod czy Jack Strong? Medialny wizerunek pułkownika Ryszarda Kuklińskiego
}

„Jam miłość, szczęście, jam niebo za młodu
Umiał poświęcić dla sprawy narodu,
Z żalem, lecz z męstwem!” (Mickiewicz, 1998)

\begin{abstract}
The article discusses the process of shaping the media image of Colonel Ryszard Kuklinski (1930-2004). The author argues that the feature film Jack Strong (directed by W. Pasikowski, Poland 2014) had importance in the public debate concerning this tragic figure in post-war Polish history. The article presents a series of journalistic materials from the press, in which the memory of R. Kuklinski is presented in dichotomous extremes between heroism and betrayal. A mixed media image of a soldier of Polish People's Army cooperating with a hostile intelligence, fosters the myth of the new incarnation of Konrad Wallenrod.
\end{abstract}

\section{Keywords:}

media image, colonel Kuklinski

1 Marek Sokołowski, Katedra Socjologii, Wydział Nauk Społecznych, Uniwersytet Warmińsko-Mazurski w Olsztynie, Polska, mar_sokolowski@op.pl. 


\section{WPROWADZENIE}

Postać pułkownika Ryszarda Kuklińskiego już od wielu lat wzbudzała i nadal wywołuje wielkie zainteresowanie nie tylko wśród badaczy zajmujących się współczesną historią Polski, ale również publicystów w związku z głośnym filmem w reżyserii Władysława Pasikowskiego - Jack Strong. Po premierze filmu, zarówno w mediach tradycyjnych (prasa, radio, telewizja), jak i nowych mediach (Internet, Facebook), na nowo przedstawiana była postać i wizerunek Ryszarda Kuklińskiego oraz pojawiła się kolejna próba rozstrzygnięcia od wielu już lat fundamentalnego pytania o bohaterstwo pułkownika czy dopuszczenie się przez niego zdrady w okresie PRL-u. Wizerunek pułkownika był odmiennie przedstawiany w poszczególnych mediach, co w pewnym sensie odzwierciedla opinie publicystów co do postaci Ryszarda Kuklińskiego. Celem niniejszego opracowania jest próba ukazania wizerunku tej postaci w mediach oraz zdiagnozowanie, czy jest on prawdziwy, czy fałszywy oraz czy został skonfrontowany z oficjalną biografią oficera (Mojsik, 2014).

Analizując publikacje na temat Ryszarda Kuklińskiego, można zauważyć, że nie wszyscy publicyści posiadają rzetelną wiedzę historyczną na temat epoki PRL-u i samego pułkownika, a wykreowany przez media obraz jest często pełen stereotypów. Zarówno przekazy medialno-prasowe, jak również film fabularny Jack Strong, który obejrzało w Polsce ponad milion widzów, wywarły znaczny wpływ na wizerunek Ryszarda Kuklińskiego. Efekt jest taki, że według sondażu IBRiS Homo Homini na temat postawy pułkownika Kuklińskiego dla 33\% pytanych jest jasne, że to bohater narodowy, a tylko 9\% badanych odpowiedziało, że to zdrajca (mod/Rzeczpospolita, 2014).

W przekazach medialnych głośno akcentowano burzę, jaka miała miejsce w trakcie debaty sejmowej nad uchwałą upamiętniającą pułkownika. W szczególności zwracano uwagę na ostre spory, jakie miały miejsce między przedstawicielami formacji postkomunistycznych a postsolidarnościowych. Pomimo upływu lat, w dalszym ciągu dla jednych to historia bohatera, dla innych - zdrajcy. Ostatecznie w uchwale sejmowej napisano m.in., że: „Kukliński odważnie przeciwstawił się komunistycznemu reżimowi, stając w jednym szeregu z bohaterami walk o polską niepodległość” (mod/Rzeczpospolita, 2014). W oświadczeniu parlamentarnym napisano ponadto, iż:

[...] Sejm RP wyraża najwyższe uznanie dla działań pułkownika, którego poświęcenie przysłużyło się obaleniu w Polsce komunizmu i utrzymaniu światowego pokoju zagrożonego ofensywnymi planami militarnymi Związ- 
ku Radzieckiego. Kierując się dobrem Polski i Polaków, nie zważając na niebezpieczeństwa, Ryszard Kukliński odważnie przeciwstawił się komunistycznemu reżimowi [...].

Przedstawienie wizerunku postaci tak niejednoznacznej i wielowymiarowej, jaką był Ryszard Kukliński nie jest sprawą łatwą, szczególnie jeśli weźmie się pod uwagę przekazy medialne. Trzeba pamiętać o tym, że w mediach kraju przechodzącego transformację systemową również następują przewartościowania i nie wykształciły się jeszcze do końca reguły odpowiadające najbardziej nowoczesnym systemom medialnym na świecie.

Ukazanie wizerunku postaci Ryszarda Kuklińskiego wiąże się, co jest sprawą niebagatelną, z istotnym w polskich realiach czynnikiem historyczno-politycznym, a osoby, które osobiście znały Ryszarda Kuklińskiego nadal są w świecie medialno-politycznym obecne. Istniejący obraz medialny zostanie skonfrontowany z materiałami historycznymi, jednakże również w tej materii sprawa jest nierozstrzygnięta, gdyż sami historycy nie są zgodni co do oceny postawy Ryszarda Kuklińskiego.

\section{MAKIAWELLIZM, „ETOS MASKI” I POETYKA TAJEMNICY}

Mając na uwadze próbę właściwego odczytania medialnego wizerunku pułkownika Ryszarda Kuklińskiego, warto zastanowić się, z czego wypływają źródła postaw, z jakimi spotkaliśmy się, studiując burzliwą historię życia polskiego oficera, czy nie tkwią one głęboko w naszym narodowym romantyzmie, ukształtowanym przez twórczość poetycką Juliusza Słowackiego, Zygmunta Krasińskiego i Adama Mickiewicza. Jaką rolę w kształtowaniu „narodowej duszy” i nowoczesnego patriotyzmu mogły odegrać dzieła tej miary, co III część Dziadów Adama Mickiewicza, ale też nieco zapomniana powieść poetycka Konrad Wallenrod? Nie sugeruję, że Ryszard Kukliński w swoich życiowych wyborach kierował się romantycznymi porywami ducha lub jedynie chłodną kalkulacją, lecz spróbujmy założyć, iż w niezwykłej biografii pułkownika, ceniącego żeglarstwo, które czynnie uprawiał, morski kodeks honorowy był równie istotny, jak kodeks oficerski, dostrzegalne są rysy narodowego patosu, heroizmu, ale też pewnej naiwności, zaskakującej u tak wytrawnego oficera i stratega. Dlatego też warto pokusić się o dokonanie pewnych paraleli postaci Kuklińskiego z bohaterem z literackich kart, jakim był Konrad Wallenrod, postać autentyczna (mistrz Zakonu w latach 1391-1393), którego życiowe wybory, używając współczesnego 
języka - polityczne kalkulacje, dyplomatyczne i militarne zdrady, przyczyniły się do klęski Krzyżaków. Czy Kukliński, jak wielu innych Polaków walczących o niepodległość ojczyzny, inspirował się w swojej działalności poetycką postacią wykreowaną przez narodowego Wieszcza? Tego nie rozstrzygniemy jednoznacznie, warto jednak, w celu późniejszych analiz medialnego wizerunku pułkownika, bliżej przyjrzeć się istocie poematu Mickiewicza, który w istotny sposób wpłynął na kilka pokoleń uczestników krajowych tajnych stowarzyszeń, spisków niepodległościowych, zbrojnych stowarzyszeń, a nawet powstań narodowych. Spór o Wallenroda (jak współczesny spór o Kuklińskiego) miał już od momentu wydrukowania poematu charakter sporu politycznego, gdyż spierając się o wartości estetyczne i moralne dzieła Adama Mickiewicza, spierano się równocześnie o to, jakimi zasadami powinno się kierować polskie społeczeństwo w sytuacji określonej postanowieniami Kongresu Wiedeńskiego. Dlatego też pisali o poemacie zarówno zwolennicy orientacji spiskowo-niepodległościowej, jak i konserwatyści broniący politycznego status quo Królestwa Kongresowego, ufający, że zachowaniem „spokojności” da się zachować przychylność „liberalnego" cara i ocalić resztki samodzielności politycznej (Chwin, 1998, s. CXXV).

Konrad Wallenrod powstał w Rosji, gdzie poeta przebywał w latach 1824-1829 jako zesłaniec polityczny na mocy sentencji wyroku, w związku z wykryciem przez władze carskie Towarzystwa Filaretów i Filomatów. Ukończone dzieło ukazało się w lutym 1828 roku w Petersburgu, co skłaniało wielu historyków do tego, by utwór Mickiewicza interpretować biograficznie, poszukując analogii między sposobem życia poety w Rosji a strategią działania głównego bohatera. Jak stwierdza Stefan Chwin, autor opracowania dzieła Mickiewicza, wybór tematyki historycznej, zdarzeń i postaci opromienionej urokiem zamierzchłej przeszłości, nie wynikał tylko ze względów cenzuralnych, gdyż doskonale mieścił się w ówczesnej estetyce romantycznej - klimat duchowy romantycznego historyzmu wpłynął na sposób myślenia poety - a wbrew zapowiedziom, zamieszczonym we wstępie do poematu, że zdarzenia, o których poeta pragnie opowiedzieć, należą do czasów zamierzchłych i nie łączą się z teraźniejszością XIX wieku, Mickiewicz podjął problematykę jak najbardziej współczesną, gdyż za „maską” średniowiecznych realiów ukrył własne doświadczenia zesłańca przebywającego w głębi zaborczego imperium, łącząc własne fascynacje postaciami „ludzi podziemnych” ówczesnego świata. „Działanie w ukryciu - w «masce», w przebraniu, przechytrzanie potężnego przeciwnika, dążenie do opanowania wrogiej organizacji przez tajnych emisariuszy - wszystkie te sytuacje typowe dla działań «człowieka podziemnego» przełomu XVIII i XIX wieku znajdowały odbicie w strukturze fabularnej powieści poetyckiej: jej akcja, w wielu punktach zbliżona do akcji romansu sensacyjnego, 
w ścisłym tego słowa znaczeniu, pośrednio odwzorowywała nie tylko dramatyczne momenty działania spiskowców, lecz także psychologiczne napięcia obecne w świadomości uczestników organizacji tajnych” (Chwin, 1998, s. IX-X).

Stworzony przez poetę Wallenrod tylko kilkoma rysami przypomina rzeczywistego Wallenroda, mistrza Zakonu, który podczas wyprawy na Litwę w roku 1392 opuścił swoją armię tuż przed rozpoczęciem oblężenia Wilna, czym przyczynił się do klęski Krzyżaków. To niezrozumiałe zachowanie wodza oraz jego późniejsza zagadkowa śmierć nasuwały przypuszczenie, że mogły nim kierować jakieś ukryte pobudki związane z tajemniczym dramatem rozgrywającym się w jego umyśle. Mickiewicz poszedł tym tropem, ale w kierunku całkowicie niezgodnym ze źródłami, tworząc szczególnego rodzaju opowieść o zamaskowanym „szpiegu”, który przeniknął do wnętrza wrogiego państwa po to, by je zniszczyć, dlatego też utwór w kilku rysach przypomina wydaną w 1821 roku powieść amerykańskiego pisarza Fenimora Coopera „Szpieg”, w której pojawia się podobna postać. Z korespondencji prowadzonej w tym czasie przez Mickiewicza wynika, iż w momencie pracy nad poematem czytał dzieła Machiavellego, u którego problematyka maski i działań zamaskowanych była rozstrzygana jednoznacznie, gdyż włoski myśliciel dobitnie formułował zasadę, że tam, gdzie chodzi o obronę zagrożonego bytu ojczyzny, wszystkie metody walki są dozwolone, sam zaś sposób działania w imię tego celu nie powinien podlegać żadnej ocenie moralnej, w sytuacji śmiertelnego zagrożenia metody działania należy wybierać wyłącznie ze względu na ich skuteczność. Motto do poematu - „Macie bowiem wiedzieć, że są dwa sposoby walczenia... trzeba być lisem i lwem” - zaczerpnął z traktatu Ksiq̨żę Machiavellego, jednakże bohater Mickiewicza nie jest osobowością makiaweliczną, ponieważ nie traktuje „maski” i strategii „zamaskowania” jako środków neutralnych etycznie; noszenie „maski” przez Konrada, rycerza chrześcijańskiego, staje się powodem jego duchowej udręki, jest bowiem niezgodne z etosem rycerskim („,zdrada” Kuklińskiego będzie niezgodna z etosem oficerskim, niezależnie od tego, mundur jakiej armii się przywdziewa). Istota doświadczenia tragicznego Konrada zawiera się w tym, że aby ocalić ojczyznę, musi Wallenrod popełnić czyny w jego odczuciu niemoralne, racją jednakże nadrzędną dla bohatera jest nakaz patriotyczny; poeta opowiada o cenie, jaką trzeba zapłacić za wierność ojczyźnie. „Dążąc do urzeczywistnienia celu obdarzonego najwyższą sankcją moralną, musi wybrać sposób walki, który splami jego honor rycerski: musi dopuścić się kłamstwa i zbrodni. Wybiera sposób działania niemieszczący się w granicach chrześcijańskiego etosu rycerskiego niczym zamaskowany skrytobójca zadaje wrogowi „cios w plecy”. Mówi o sobie, że musi zdradzać i mordować” (Chwin, 1998, s. XLIV). Towarzyszy mu poczucie 
splugawienia; aby dojść do najwyższych zaszczytów w państwie krzyżackim, Konrad musiał brać udział w wielu przedsięwzięciach budzących w nim odrazę, (vide: Kukliński), zachowanie „czystych rąk” w realizacji jego planu jest trudno wyobrażalne. W celu zdobycia najwyższych urzędów w Zakonie (vide: Sztab Generalny LWP, gdzie pracował Kukliński), by w ten sposób uzyskać możliwość ocalenia ojczyzny, Wallenrod musiał działać zgodnie z interesami Zakonu, a zatem bezpośrednio przeciw własnej ojczyźnie, gdyż tylko w ten sposób mógł zasłużyć na zaufanie Krzyżaków. Nie dziwi zatem, że pozorny charakter średniowiecznego sztafażu dostrzegli już pierwsi czytelnicy poematu, odczytując go w poetyce „historyzmu maski”, zauważając symboliczne zobrazowanie dylematów wielu Polaków, zmuszonych przez okoliczności historyczne do zastąpienia wojskowych form walki, w tym otwartych powstań narodowych, formami walki spiskowej.

\section{METODY BADANIA WIZERUNKU}

Metody badania wizerunku są współcześnie bardzo rozbudowane i wielowymiarowe, co w znacznej mierze jest pochodną zachodzenia na siebie wielu dziedzin życia: społecznego, politycznego, ekonomicznego, kulturalnego. Do tego dochodzi dynamicznie zmieniający się i bardzo rozpowszechniony przekaz medialny. Od niedawna funkcjonuje w Polsce nie do końca jeszcze rozpoznane pojęcie marketingu medialnego. Jest to termin, który wraz z postępującym umasowieniem i interaktywnością mediów zyskuje coraz większą popularność. Jego obecność zauważalna jest nie tylko na polu medialnym, ale również polityczno-społecznym i publicystycznym (Jupowicz-Ginalska, 2010, s. 5-25).

Przystępując do ukazania metod badania wizerunku, należy bliżej przyjrzeć się samemu pojęciu „wizerunek”. Nie ulega wątpliwości, że wizerunek danej postaci jest tylko pozornie kategorią intuicyjną. Samo pojęcie „,wizerunek” może oznaczać zarówno obraz, fotografię lub inną graficzną reprezentację przedmiotu czy osoby, może się również odnosić do reprezentacji przedmiotu w umyśle postrzegającej go osoby, jak i do wszystkich elementów tej reprezentacji z osobna (Gackowski, Łączyński, 2009, s. 80).

Na budowanie wizerunku składa się wiele skomplikowanych procesów. Sukces (lub porażka) w tworzeniu medialnego wizerunku w dużej mierze zależy od tego, czy w sposób umiejętny dany podmiot lub podmioty posługują się zróżnicowanymi technikami, w tym marketingowo-reklamowymi.

Nie trzeba było długo czekać do momentu, kiedy postać pułkownika Kuklińskiego została wykorzystana w podobny sposób. Świadczy o tym spot reklamowy 
formacji, która brała udział w wyborach do Parlamentu Europejskiego - Solidarnej Polski, którego bohaterem został Kukliński. Są w nim również fragmenty filmu Jack Strong. Solidarna Polska przypomina w klipie, że walczyła o dobre imię Kuklińskiego na długo przed tym, jak zainteresowali się nim inni politycy. Hasło wyborcze Solidarnej Polski „Mamy siłę, aby iść pod prąd” również nawiązuje do życiorysu pułkownika Kuklińskiego (Kolanko, 2014).

Niezależnie od preferowanych poglądów przez przedstawicieli poszczególnych mediów (prasowych, telewizyjnych, internetowych) oraz reprezentowanego przez nie nurtu i formy przekazu, praktycznie wszystkie w ciągu wielu tygodni po premierze filmu, nawiązując do postaci Kuklińskiego, prezentowały jego życiorys. „Gazeta Wyborcza” nawiązała do okupacyjnej przeszłości rodziny Kuklińskiego, której doskwierała bieda, a mały Ryszard obserwował wszelkie okropności wojny - łapanki oraz egzekucje. Tuż po wojnie, jako piętnastoletni chłopiec, rozpoczął pracę w Miejskiej Straży Ochrony Obiektów we Wrocławiu, jako ochroniarz w fabryce mydła. Stamtąd w dwa lata później trafił do Oficerskiej Szkoły Piechoty we Wrocławiu. Odtąd zaczęła się jego wojskowa i polityczna kariera (Wąs, 2014).

W roku 1952 Ryszard Kukliński ożenił się z Joanną, córką swego przełożonego z czasów, kiedy pracował we Wrocławiu. Mieli dwóch synów: Bogdana i Waldemara. Kukliński dość szybko piął się po szczeblach kariery wojskowej. Już w roku 1963 pracował w Sztabie Generalnym, ukończył studia w Akademii Sztabu Generalnego Wojska Polskiego, a w roku 1967 dostał stopień podpułkownika. Angażowano go w tamtym czasie do szczególnych zadań i misji. Przez rok (1967-1968) przebywał w wietnamskim Sajgonie, dokąd Polska wysłała oficerów do międzynarodowej misji nadzorującej przestrzeganie układu genewskiego z roku 1954 o granicy między północną a południową częścią tego kraju. Niektórzy podejrzewają, że już wtedy Ryszard Kukliński rozpoczął współpracę z CIA. Jest to jednak teza najczęściej podnoszona przez przeciwników Kuklińskiego (Wąs, 2014).

Pobyt w Wietnamie, gdzie Kukliński zetknął się z żołnierzami USA, był niewątpliwie istotnym doświadczeniem. Później konsekwentnie powtarzał, że praca w sztabie spowodowała jego metamorfozę - sowieckie plany wojny z Zachodem oznaczały zagładę ludności Polski. „Gazeta Wyborcza” podaje, że w tamtym czasie Kukliński „„...] wiódł życie wysoko postawionego oficera LWP. Jak na standardy PRL komfortowe, dziś powiedzielibyśmy, że skromne; trzypokojowe mieszkanie na piątym piętrze wojskowego wieżowca przy ulicy Olbrachta w Warszawie, czteroletni opel, żona była księgową w tokarni” (Wąs, 2014). 


\section{BOHATER CZY ZDRAJCA?}

Wiadomości dotyczące życiorysu pułkownika Kuklińskiego były prezentowane nie tylko w mediach ogólnopolskich, ale również w mediach regionalnych. „Gazeta Olsztyńska” opublikowała wywiad z badaczem zajmującym się współczesną historią Polski prof. Dariuszem Radziwiłłowiczem. Na pytanie, czy Kukliński to bohater czy zdrajca, historyk odpowiedział: „,...] na pewno nie zdrajca. Mam takie przekonanie, że chyba działał ze szlachetnych pobudek. Natomiast trudno jest się ustosunkować do opinii wygłaszanych przez jego przeciwników, którzy twierdzą, że brał pieniądze i kierował się dobrami materialnymi” (Sawicka, 2014). Paweł Majewski pisał na łamach „Rzeczpospolitej”, że:

[...] więcej jest dobrze oceniających słynnego szpiega niż uznających go za zdrajcę. Martwi jednak postawa największej grupy badanych (około 30\%), którzy nie potrafią go ocenić, co bardzo źle świadczy o kondycji moralnej naszego społeczeństwa i jest to wynik propagandy postkomunistycznej, która przy okazji ostatnich dyskusji przekonywała, że trzeba się wstrzymać od oceny, bo nie wszystko jeszcze na ten temat jest wiadome (Majewski, 2014).

Pozytywnie oceniał na łamach „Newsweeka” postać Kuklińskiego Tomasz Lis, pisząc: „[...] mam nadzieję, że jeszcze przed rocznicą 4 czerwca pułkownik Kukliński będzie zarówno generałem Kuklińskim, jak i kawalerem Orderu Orła Białego” oraz że „[...] najbardziej zaciekłymi przeciwnikami pułkownika Kuklińskiego, propagatorami idiotycznej tezy o jego zdradzie są ci, którzy zapewne do dziś dzielnie broniliby PRL, gdyby tylko PRL istniał”. Wskazał ponadto, że:

[...] Pułkownik Kukliński powinien być wielkim wyrzutem naszej, już nowej Polski. Potrzebowała ośmiu lat, by przywrócić mu prawa i honor, a uczyniła to tylko ze względu na amerykańską presję w przededniu wejścia naszego kraju do NATO. Po ćwierćwieczu nasze rachunki z Kuklińskim wciąż nie są wyrównane. A powinny być, jeszcze zanim - a to już za chwilę - będziemy obchodzić rocznicę wejścia Polski do NATO i do wspólnoty demokratycznych narodów (Lis, 2014).

Tomasz Lis przywołuje również opinie oraz oceny krytyków pułkownika Kuklińskiego. Zwraca uwagę na jednego z czołowych krytyków, jakim jest gen. Gromosław Czempiński, który w wywiadzie udzielonym tygodnikowi „Wprost” stwierdził, że: „„...] ludzie z wywiadu mają wątpliwości, kim był naprawdę i co 
sobą reprezentował Kukliński. Nam jest trudno myśleć o nim w kategoriach bohatera, ponieważ dla oficera wywiadu zdrada to zdrada” (kl, Radio Zet, 2014).

„Newsweek” powoływał się również na opinie innych znanych osobistości politycznych. Jedną z nich był ówczesny szef resortu spraw zagranicznych Radosław Sikorski, który w następujący sposób odniósł się do sprawy pułkownika: „Kukliński zdradził PRL. Złamał przysięgę na wierności Polsce Ludowej i Związkowi Radzieckiemu. Tylko, że Polska Ludowa nigdy nie reprezentowała interesów narodu polskiego. Płk Kukliński zdradził państwo w interesie narodu. Gdy zorientował się, że Polska jest ściśle podporządkowana Związkowi Radzieckiemu, gdy spostrzegł, że radzieckie plany militarne narażają nas na ryzyko odwetu nuklearnego ze strony NATO, gdy wyobraził sobie radzieckie sądy polowe dla Polaków odmawiających rozkazu inwazji na Zachód - przeraził się. Przeraził się skutków dla narodu wynikających z wierności państwa polskiego radzieckiemu sojusznikowi. I dlatego postanowił pomóc Zachodowi w uniemożliwieniu realizacji apokaliptycznego scenariusza” (Kalukin, 2014).

W zupełnie innym świetle była i jest przedstawiana postać Kuklińskiego na łamach tygodnika „Nie”. Jerzy Urban, były rzecznik prasowy rządu z okresu stanu wojennego, wiele razy dawał wyraz swojej niechęci wobec postaci Kuklińskiego. Urban pisał kiedyś, że „,...] Ryszard Kukliński był długotrwałym, wysoko płatnym szpiegiem USA. Jest zdrajcą swojej ojczyzny [...]”, „,...] byłoby poniżej godności rządu polskiego spieranie się z pohańbionym zdrajcą” (Szaniawski, 2004, s. 219-221).

W podobnym tonie Urban wypowiadał się na początku 2014 roku: „[...] czynienie z niego bohatera zachęca innych oficerów, aby na przykład współpracowali z Rosją, która podobno ma lub może mieć wycelowane w Polskę rakiety” (Pac/ NaTemat, 2014).

W artykułach zamieszczonych na łamach „Nie” również można było znaleźć krytyczny stosunek zarówno do postaci samego Ryszarda Kuklińskiego, jak również wobec filmu Jack Strong. Agnieszka Wołk-Łaniewska pisała:

Nie mam pretensji do Władysława Pasikowskiego, który zrobił prostacki western o Ryszardzie Kuklińskim. Taka jest natura westernu, a wybitny reżyser mógł odczuwać potrzebę zrehabilitowania się w oczach Polski patriotycznej i antykomunistycznej. Nie tylko za «Pokłosie», ale także za uznane za najlepszy film sensacyjny po roku 1945 «Psy», w których głównym bohaterem był dobry esbek. I to nie resortowy Winkelried potajemnie służący «Solidarności», tylko szczery oficer Polski Ludowej. W fabularyzowanej biografii Kuklińskiego Pasikowski miał prawo zrobić ze swojego bohatera skrzyżowanie Chucka 
Norrisa z Misiem Kolargolem, a ja mam prawo tego nie oglądać. Gorzej, jeżeli propagandowy i rojący się od łgarstw życiorys Kuklińskiego cytowany jest bezkrytycznie w depeszy PAP, powielanej przez media, z «Gazetą Wyborczą» na czele [...] (Wołk-Łaniewska, 2014).

Ścierają się ze sobą dwa różne sposoby oceny pułkownika Ryszarda Kuklińskiego. Przebiegają one wzdłuż linii podziału na zwolenników postsolidarności oraz zwolenników ugrupowań postkomunistycznych. Ci pierwsi lansują Kuklińskiego jako bohatera, o czym świadczy na przykład wypowiedź Romana Kobo - prezesa Kongresu Polaków w Szwecji, który stwierdził, że:

pułkownik Kukliński przyczynił się bardzo jako polski oficer do obrony Ameryki i świata demokracji zachodniej przed imperium sowieckim. Pułkownik Kukliński odegrał w historii USA i Polski taką rolę, jak Pułaski i Kościuszko. Podobnie jak generał Pułaski, również Kukliński został skazany na śmierć przez polski sąd za to, że walczył z Rosją o wolność Polski (Szaniawski, 2004, s. 230-231).

Z kolei dla drugich jest zdrajcą, o czym świadczy wypowiedź Danuty Waniek, byłego ministra w kancelarii prezydenta Aleksandra Kwaśniewskiego, która tak mówiła o Kuklińskim:

[...] w dalszym ciągu uważam Kuklińskiego za zdrajcę i szpiega. Na miejscu Millera nie spotkałbym się z nim nigdy. Kukliński złamał przysięgę wojskową, zdradził armię i Państwo Polskie. Wiadomo, iż czynił to z pobudek materialnych. Wmawianie społeczeństwu, iż szpieg i zdrajca jest bohaterem narodowym, ośmiesza jedynie kręgi prawicowe, które uczyniły z Kuklińskiego swój sztandar. Kukliński przez ponad 30 lat był oficerem Wojska Polskiego, a jego szpiegowska działalność była skierowana przeciwko temu wojsku i przeciwko państwu. Kuriozalne jest nazywanie go pierwszym Polakiem w NATO. Polska Rzeczpospolita Ludowa istniała (Szaniawski, 2004, s. 221).

Przedstawiciele mediów określających się jako narodowe, patriotyczne i prawicowe na ogół przedstawiają pułkownika Kuklińskiego jako bohatera. Z kolei w mediach lewicowo-liberalnych jest on przedstawiany nieco inaczej. Wiele z nich nie stwierdza wprost, że Kukliński był zdrajcą, ale wyraża raczej powściągliwość w uznawaniu go za bohatera. 
Postać pułkownika Kuklińskiego była tematem artykułu w tygodniku „Do Rzeczy”. Cezary Gmyz i Wojciech Wybranowski podkreślają, że dotarli do wielu wcześniej nieznanych dokumentów (Gmyz, Wybranowski, 2014). Poza wieloma informacjami o randze historycznej, autorzy polemizują również z artykułami oraz poglądami, które przedstawiają pułkownika w negatywnym świetle. Piszą, że „komunistyczna, propagandowa agitka sprowadzająca płk Kuklińskiego do roli pazernego sprzedawczyka funkcjonuje do dnia dzisiejszego i najczęściej jest powielana przez takich funkcjonariuszy służb jak gen. Gromosław Czempiński, którzy do końca wiernie służyli komunistycznemu systemowi” (Gmyz, Wybranowski, 2014).

Przed premierą filmu Jack Strong, portal wPolityce.pl słowami Piotra Junkera przypominał, że „najnowszy film Władysława Pasikowskiego daje nadzieję na zmianę masowej świadomości Polaków w sprawach historii najnowszej, w której czy się to komuś podoba, czy też nie - jedną z najważniejszych osi stanowi postać Pułkownika Kuklińskiego” (Junker, 2014).

\section{PROSTACKI WESTERN CZY SENSACYJNY FILM SZPIEGOWSKI?}

Znaczna część artykułów, które poruszały problematykę związaną z Kuklińskim, nawiązywała do przywoływanego już filmu Jack Strong w reżyserii Władysława Pasikowskiego reklamowanego jako: „film sensacyjny, będący prawdziwą historią pułkownika Ryszarda Kuklińskiego - człowieka, który tkwiąc w środku systemu, podejmuje współpracę z wywiadem USA i stał się kluczowym (choć niewidocznym) aktorem czasu zimnej wojny” (www.jackstrongfilm.com, 2016).

Mariusz Cieślik na łamach „Rzeczpospolitej” pisał:

[...] na przykładzie „Pokłosia” i „Jacka Stronga” widzimy, jak kino może wpływać na opinię publiczną i wizerunek kraju. Przypadek obrazu „Jack Strong” o pułkowniku Kuklińskim dowodzi, że politykę państwa kształtuje się również przez wspieranie produkcji filmowej. Ten, kto twierdzi, że zawsze decydujący jest poziom artystyczny, nie rozumie, jak działa ten mechanizm (Cieślik, 2014).

Publicysta uważa też, że „sukces filmu zamknął dyskusję na temat pułkownika Ryszarda Kuklińskiego. Znalazło to wyraz w uchwale Sejmu, niepozostawiającej wątpliwości, że mamy do czynienia z bohaterem. A przecież w przypadku szpie- 
gów jakieś wątpliwości można mieć, mówimy wszak o sferze wyborów trudnych i niejednoznacznych, z czym zgodzą się chyba zarówno najwięksi zwolennicy, jak i najgorętsi przeciwnicy «pierwszego polskiego oficera w NATO»” (Cieślik, 2014).

„Gazeta Wyborcza” zamieściła wywiad z reżyserem filmu - Władysławem Pasikowskim, który powiedział, że:

wszystkie zdarzenia ukazane w filmie są prawdziwe. Nie wszystko jest ukazane, bo film jest krótszy niż życie. Pułkownik miał swoją bohaterską stronę i to ona mnie zainteresowała, i - mam nadzieję - zainteresuje widzów. Miał też codzienną stronę, na przykład palił sto papierosów dziennie i takie tam... I ta strona mnie nie interesowała, bo jestem gawędziarzem, a nie spowiednikiem ani prokuratorem. Nie mówiąc już o tym, że ludzie by mi nie darowali kolejnych papierosów w filmie [...] (Subbotko, 2014).

Rafał Bieńkowski na łamach „Gazety Olsztyńskiej” pisał, że Jack Strong to:

bardziej sprawnie nakręcona sensacja niż film szpiegowski w stylu słynnego «Szpiega» Tomasa Alfredsona z Garym Oldmanem w roli głównej [...]. Grany przez Marcina Dorocińskiego Kukliński nie jest postacią jak z posągu. I chociaż podczas pierwszych spotkań z agentem CIA jest pewny siebie, to szybko się to zmienia. Co chwila widzimy, jak targają nim wątpliwości, strach, czasami sprawia wrażenie, że wieloletnia konspiracja go przerasta. Tak jak w scenie, kiedy w obecności przełożonego, który informuje o przecieku, sparaliżowany wyciera mokrą twarz kartką papieru. Od przyznania się do wszystkiego dzieliły go milimetry. Mimo to dalej wykonywał swoje zadanie. «Jack Strong» jeszcze przed premierą rozpoczął kolejną dyskusję o tym, czy Ryszard Kukliński zdradził kraj, czy jednak uchronił go przed widmem trzeciej wojny światowej i «zrobieniem z Polski drugiej Hiroszimy» (Bieńkowski, 2014).

W zdecydowanej większości przekazów medialnych, które pojawiły się w związku z filmem, można było zauważyć, że pułkownik Kukliński był przedstawiany jako bohater, który poświęcił swoje życie zawodowe i prywatne dla dobra sprawy narodowej. 


\section{IKONA PRAWICY CZY POPKULTUROWY HEROS? PRÓBA PODSUMOWANIA}

Podsumowując przywoływane opinie, warto przywołać fragment listu otwartego, jaki do Lecha Wałęsy napisał Zbigniew Herbert:

Argument, że pułkownik Kukliński był zdrajcą, w myśl obowiązujących w PRL praw, jest formalnie słuszny, ale całkowicie absurdalny, gdyż musielibyśmy wyrzucić z podręczników szkolnych nazwiska Pułaskiego, Traugutta i Piłsudskiego. Pułkownik Kukliński przez wiele lat toczył samotną walkę, w cieniu grożącej mu w każdym momencie śmierci - o sprawy najważniejsze: prawo do niezawisłości, prawo do obrony zagrożonego bytu państwowego, o godność narodową wreszcie (Krajewski, 2014).

Przywołując tego typu opinie zauważmy, że ważną kwestią w ocenie sylwetki Kuklińskiego jest często dany światopogląd polityczny osoby, która jej dokonywała, oraz zapatrywanie na niedawną przeszłość polityczną Polski, stosunek do dziedzictwa PRL-u, siłą rzeczy rzutujący na opinię, stąd tak wiele emocjonalnych słów, pełnych żaru, gorących, które wraz z upływem czasu, jaki minął od śmierci pułkownika, wciąż nie wystygły i potrafią skutecznie rozpalić niejedną polityczną debatę. Dlatego też spór wokół Kuklińskiego oraz jego medialny wizerunek jeszcze przez wiele lat będą się sprowadzały do jego pozytywnej i negatywnej oceny, ale dla przyszłych pokoleń legenda Kuklińskiego przetrwa zapewne głównie dzięki filmowi Pasikowskiego, sam zaś pułkownik może „zyskać twarz” odtwarzającego go w filmie Marcina Dorocińskiego, gdyż taka jest medialna siła rażenia kina popularnego, bez względu na to, czy akceptujemy ów stan rzeczy, czy też nie. Postać oraz wizerunek Ryszarda Kuklińskiego stały się pewną ikoną w polskim życiu społecznym oraz politycznym. Spór ideowy o dokonania Ryszarda Kuklińskiego będzie zapewne trwał przez wiele lat.

Przekaz medialny ukazujący Ryszarda Kuklińskiego jest na łamach polskich mediów zróżnicowany, co jest szczególnie zauważalne w publicystyce zaliczanej do prawicowej oraz lewicowo-liberalnej. Tygodniki „Do Rzeczy” lub „W Sieci” przedstawiały Kuklińskiego wyłącznie jako bohatera narodowego, w przekazach na łamach czasopism prawicowych lub narodowych Kukliński był pokazywany jako postać heroiczna.

Prasa lewicowo-liberalna z kolei doceniała wprawdzie film, podkreślając, że Władysław Pasikowski, dołożył wiele starań, by Ryszarda Kuklińskiego, pułkownika Wojska Polskiego i amerykańskiego szpiega, w filmie przedstawić 
w korzystnym świetle, wskazywała jednak na wiele niedociągnięć i mankamentów. W jednym z artykułów zamieszczonych na stronie „Lewica Razem” (Kułaga, 2014) przywołano opinię legendarnego kuriera i emisariusza polskiego Państwa Podziemnego, Jana Karskiego, który w wywiadzie dla „Przeglądu Tygodniowego” w 1998 roku powiedział: „,życie szpiega to ciągłe kłamstwa, oszustwa, szantaż, kradzież. To także codzienny strach. Niepodległość odzyskaliśmy nie dlatego, że Kukliński przekazywał tajne plany Paktu Warszawskiego Stanom Zjednoczonym”.

\section{Bibliografia:}

Bieńkowski, R. (2014). Historia na ekranie - Litry potu pod kartką papieru. Gazeta Olsztyńska, 08-09.02.2014.

Chwin, S. (1998). Wstęp. XII recepcja w Polsce. W: A. Mickiewicz, Konrad Wallenrod. Wrocław: Ossolineum.

Cieślik, M. (2014). Kino też robi politykę. Rzeczpospolita, 27.02.2014.

Gackowski, T., Łączyński, M. (2009). Metody badania wizerunku w mediach: czym jest wizerunek, jak i po co należy go badać. Łódź: CeDeWu.Pl.

Gmyz, C., Wybranowski, W. (2014). „Jack Strong” - przeciek z Watykanu. Do Rzeczy, 7, 10-16.02.2014.

Junker, P. (2014). Pułkownik Kukliński - moja opowieść. „W tym stanie rzeczy, najnowszy film Władysława Pasikowskiego daje nadzieję na zmianę masowej świadomości Polaków w sprawach historii najnowszej”, 05.02.2014. Pobrane z: http://wpolityce. pl/polityka/184820-pulkownik-kuklinski-moja-opowiesc-w-tym-stanie-rzeczynajnowszy-film-wladyslawa-pasikowskiego-daje-nadzieje-na-zmiane-masowejswiadomosci-polakow-w-sprawach-historii-najnowszej.

Jupowicz-Ginalska, A. (2010). Marketing medialny. Warszawa: Difin.

Kalukin, R. (2014). Zdradził państwo w interesie narodu: Sikorski o Kuklińskim, 6.02.2014. Pobrane z: http://polska.newsweek.pl/radoslaw-sikorski-o-plk-ryszardzie-kuklinskimwywiad-na-newsweek-pl,artykuly,280293,1.html.

kl, Radio Zet (2014). Czempiński: w moich kategoriach Kukliński to zdrajca, 5.02.2014. Pobrane z: http://www.wprost.pl/ar/435043/Czempinski-W-moich-kategoriachKuklinski-to-zdrajca/.

Kolanko, M. (2014). Kukliński w spocie SP. „Mamy siłę, aby iść pod prąd”, 1.04.2014. Pobrane z: http://300polityka.pl/news/2014/04/01/kuklinski-w-spocie-sp-mamy-sile-aby-isc-pod-prad/.

Krajewski, A. (2014). Zasługa dla Polski. Pułkownik Ryszard Kukliński opowiada swoją historię, e-book.

Kułaga, Z. (2014). Jack Strong, 20.02.2014. Pobrane z: http://www.lewicarazem.pl/jack-strong/.

Lis, T. (2014). Kukliński na generała, 10.02.2014. Pobrane z: http://opinie.newsweek. pl/felieton-redaktora-naczelnego-tomasza-lisa-newsweek-pl,artykuly,280408,1.html. Mickiewicz, A. (1998). Konrad Wallenrod. Wrocław: Ossolineum. 
mod/Rzeczpospolita (2014). Polacy uważają Kuklińskiego za narodowego bohatera! 10.03.2014. Pobrane z: http://www.fronda.pl/a/polacy-uwazaja-kuklinskiego-zanarodowego-bohatera,35275.html.

Mojsik, A. (2014). Medialny wizerunek pułkownika Ryszarda Kuklińskiego. Prawda czy fałsz, praca niepublikowana, Olsztyn.

Pac/NaTemat (2014). Płk. Kuklińskiego ocenił... Jerzy Urban, 6.02.2014. Pobrane z: http:// www.fronda.pl/a/plk-kuklinskiego-ocenil-jerzy-urban,34223.html.

Sawicka, W. (2014). Bohater czy zdrajca? Gazeta Olsztyńska, 8-9.02.2014.

Subbotko, D. (2014). Pasikowski o Kuklińskim - wywiad z reżyserem filmu „Jack Strong”, 3.02.2014. Pobrane z: http://wyborcza.pl/1,75475,15382007,Pasikowski_o_Kuklinskim_wywiad_z_rezyserem_filmu.html.

Szaniawski, J. (2012). Imperium zła. Rosja przeciw Polsce i Europie. Warszawa: Ex Libris. Szaniawski, J. (2004). Pułkownik Kukliński. Misja Polski. Warszawa: Ex Libris.

Szaniawski, J. (2003). Samotna misja. Pułkownik Kukliński i zimna wojna. Warszawa: Ex Libris.

Wąs, M. (2014). Ryszard Kukliński - bohater Polski czy Amerykański? Gazeta Wyborcza. Ale historia, 03.02.2014.

Weiser, B. (2005). Ryszard Kukliński. Życie ściśle tajne. Warszawa: Wyd. Świat Książki. Wołk-Łaniewska, A. (2014). Kukliński bez bielizny. NIE, 6. 